\title{
The press publishers' right in the European Union: an overreaching proposal and the future of news online
}

Book or Report Section

Accepted Version

Karapapa, S. (2018) The press publishers' right in the European Union: an overreaching proposal and the future of news online. In: Bonadio, E. and Lucchi, N. (eds.) NonConventional Copyright: Do New and Non-traditional Works Deserve Protection? Edward Elgar, pp. 316-339. ISBN 9781786434067 Available at http://centaur.reading.ac.uk/75767/

It is advisable to refer to the publisher's version if you intend to cite from the work. See Guidance on citing.

Publisher: Edward Elgar

All outputs in CentAUR are protected by Intellectual Property Rights law, including copyright law. Copyright and IPR is retained by the creators or other 
copyright holders. Terms and conditions for use of this material are defined in the End User Agreement.

\section{www.reading.ac.uk/centaur}

\section{CentAUR}

Central Archive at the University of Reading

Reading's research outputs online 


\title{
THE PRESS PUBLICATION RIGHT IN THE EUROPEAN UNION: AN OVERREACHING PROPOSAL AND THE FUTURE OF NEWS ONLINE
}

Professor Stavroula Karapapa, School of Law, University of Reading

Pre-publication version

Forthcoming in E. Bonadio and N. Lucchi (eds.), Non-Conventional Copyright: Do New and Non-Traditional Works Deserve Protection?, Edward Elgar, 2018.

\begin{abstract}
The proposed press publication right aims to provide news publishers with an additional layer of copyright protection. Following a number of controversial national initiatives, such as the German and Spanish laws on news aggregators (the so-called 'Google tax'), it aspires to offer a solution to the so-called 'newspaper crisis'. However, the proposed right is not an appropriate measure for addressing declining revenues in the press publishing sector in Europe. There is no hard evidence that the right can achieve its stated objectives, notably to facilitate rights clearance and enforcement in the press publishing industry, and its scope and duration are excessive. The protectable subject matter is defined more broadly than what the Commission seems to intend, and the right is designed to cover a number of digital activities beyond hyperlinking, such as scanning, indexing, posting snippets, certain forms of text mining, and headlines embedding links. This could have the effect of affording protection to information rather than original subject matter, possibly resulting in a monopolisation of information that goes against basic principles of copyright protection.
\end{abstract}

\section{Keywords}

Open internet; future of press publishing; right to press publications; right to access information; snippets; hyperlinks; presumption of representation; ancillary right; licensing mechanisms

\section{i. Introduction}


Since 2000, revenues in the press-publishing sector and newspaper-advertising sales have dropped ${ }^{1}$ and they are expected to drop even further. According to the figures offered in the Commission's Impact Assessment on the Modernisation of EU Copyright Rules, ${ }^{2}$ print circulation of daily newspapers has been constantly declining for years, ${ }^{3}$ whereas at the same time digital audiences of newspapers and magazines have been growing exponentially. What is more, web traffic has doubled over the past five years, ${ }^{4}$ and it is estimated that the websites and apps of newspapers and magazines are the main services used to access news for $42 \%$ of users in the EU. In its global entertainment and media outlook for 2016-2020, Price Waterhouse Coopers (PwC) estimates that global newspaper revenues are expected to decline at 1.5\% compounded annually and global newspaper advertising is expected to drop at $2.9 \%$ compounded annually. ${ }^{5}$ Similarly, Magna's global advertising forecast indicates that print media advertising salesexcluding digital revenues from publishing companies—decreased by $10 \%$ in $2016 .{ }^{6}$ In the UK alone, as reported in the Financial Times, revenues from print advertising were expected to fall by between 15 and 20\% in 2016, following a 15\% fall in 2015. To a large extent, this drop in revenues and advertising sales is due to the competition that press publishers face from a multiplicity of alternative sources, most of which are available online for free. Indeed, as the $\mathrm{PwC}$ outlook stresses, 'the general trend is that the more

\footnotetext{
${ }^{1}$ Gareth Price, Opportunities and Challenges for Journalism in the Digital Age: Asian and European Perspectives, Chatham House - THe Royal Institute of International AfFairs 3 (Aug. 25, 2015), http://www.asef.org/images/docs/Final\%20Chatham\%20House\%20Monograph-ERT7-20150825.pdf (last access Nov. 8, 2017).

2 See Commission Staff Working Document: Impact Assessment on the Modernisation of EU Copyright Rules, accompanying the document Proposal for a Directive of the European Parliament and of the Council on Copyright in the Digital Single Market and Proposal for a Regulation of the European Parliament and of the Council laying down Rules on the Exercise of Copyright and Related Rights applicable to Certain Online Transmissions of Broadcasting Organisations and Retransmissions of Television and Radio Programmes, SWD(2016) 301 final, Vol. 1, 155 (Sept. 14, 2016).
}

${ }^{3}$ By $17 \%$ in the period 2010-2014 in 8 EU Member States.

${ }^{4}$ From 248.4 to 503.4 million unique users between 2011 and 2015.

5 PwC, Global Entertainment \& Media Outlook 2016-2020, Newspapers \& Magazines: Transitioning from a Print Past to a Digital Future - Triggering New Strategies and Wide Divergences Between Markets, PWC 1 (2016), https://www.pwc.com/gx/en/entertainment-media/pdf/newspapers-and-magazines-outlook-article.pdf (last access Nov. 8, 2017).

${ }^{6}$ Daily newspapers $-11 \%$ to $\$ 12.4$ billion, magazines $-9 \%$ to $\$ 8.5$ billion. See Vincent Letang \& Luke Stillman, Global Advertising Forecast. Winter Update, MAGNA 7 (Dec. 5, 2016), https://www.magnaglobal.com/wp-content/uploads/2016/12/MAGNA-December-Global-ForecastUpdate-Press-Release.pdf (last access Nov. 8, 2017).

${ }^{7}$ David Bond, UK Newspapers Team up to Combat Falling Revenues: Owners Explore Ways of Putting Old Rivalries Aside to Work. Together, FINANCIAL TIMES (Oct. 23, 2016), https://www.ft.com/content/8c3e8c70-979a11e6-a1dc-bdf38d484582?mhq5j=e1 (last access Nov. 8, 2017). 
digitized a country's newspaper industry, the faster its overall revenue are projected to decline'.

In order to empower press publishers vis-à-vis news aggregators and online media monitoring services, a number of initiatives were introduced across Europe. In some Member States, such as Belgium, France and Italy, Google and national press publishers concluded special agreements on the use of newspaper articles in Google News; ${ }^{9}$ whereas other Member States, notably Germany and Spain, adopted legislative initiatives with regards to the online exploitation of news content (the so-called 'Google $\left.\operatorname{tax}{ }^{\prime}\right)$.

Following a public consultation, ${ }^{10}$ on 14 September 2016, the Commission published a proposal for a Directive on Copyright in the Digital Single Market, which included-inter alia-the provision affording press publishers the exclusive rights of reproduction and making their press publications available for digital use. The provision is included in Article 11 of the proposal, under the heading 'Protection of press publications concerning digital uses':

1. Member States shall provide publishers of press publications with the rights provided for in Article 2 and Article 3(2) of Directive 2001/29/EC for the digital use of their press publications.

2. The rights referred to in paragraph 1 shall leave intact and shall in no way affect any rights provided for in Union law to authors and other rightholders, in respect of the works and other subject-matter incorporated in a press publication. Such rights may not be invoked against those authors and other rightholders and, in particular, may not deprive them of their right to exploit their works and other subject-matter independently from the press publication in which they are incorporated.

3. Articles 5 to 8 of Directive 2001/29/EC and Directive 2012/28/EU shall apply mutatis mutandis in respect of the rights referred to in paragraph 1.

\footnotetext{
${ }^{8}$ PwC, Global Entertainment \& Media Outlook 2016-2020 (supra note 5).

9 See e.g. Rick Mitchell, France: Copyrights - Businesses Welcome Google Deal with Government, Publishers in France, 27(3) W.I.P.R. 13 (2013).

${ }^{10}$ European Commission, Public Consultation on the Role of Publishers in the Copyright Value Chain and on the Panorama Exception', Digital Single Market (Mar. 23, 2016), https://ec.europa.eu/digital-singlemarket/en/news/public-consultation-role-publishers-copyright-value-chain-and-panorama-exception (last access Nov. 8, 2017).
} 
4. The rights referred to in paragraph 1 shall expire 20 years after the publication of the press publication. This term shall be calculated from the first day of January of the year following the date of publication.

The right to press publications received the supportive votes of Members of the European Parliament voting in the European Parliament's Committees on Culture and Education (CULT) and Industry, Research and Energy (ITRE) on 11 July $2017 .{ }^{11}$

This vote, however, followed intense opposition from various parliamentary Committees and national delegations. Just over a year after the proposal was published, the Committee on the Internal Market and Consumer Protection of the European Parliament (IMCO) suggested in its draft Opinion the deletion of Article 11, on the basis that it lacked sufficient justification and was not appropriate in achieving its objectives ${ }^{12}$ - a position that was not reiterated in the Committee's final Opinion. ${ }^{13}$ The CULT Committee had opined that the proposed right should be subject to fundamental revisions if it was to be accepted by the Parliament, ${ }^{14}$ and the Committee on Legal Affairs (JURI) had also put forward substantive amendments to the proposed right. ${ }^{15}$ Various

\footnotetext{
${ }^{11}$ See European Parliament (Rapporteur: Zdzisław Krasnodecbski), Opinion of the Committee on Industry, Research and Energy for the Committee on Legal Affairs Committee on Industry, Research and Energy on the Proposal for a Directive of the European Parliament and of the Council on Copyright in the Digital Single Market (COM(2016)0593 C8-0383/2016 - 2016/0280(COD)), PE592.363v03-00, ITRE_AD(2017)592363 (Aug. 1, 2017). It should be noted that although the draft Opinion of the ITRE Committee (PE 592.363v01-00, ITRE_PA(2017)592363) did not include any amendments on the right to press publications, the right and its scope were heavily debated during the stage of suggesting amendments for inclusion in the final Opinion of the Committee (PE 592.364v01-00, ITRE_AM(2017)592364), with the position of numerous members of the Committee being to delete Article 11 and accompanying recitals altogether. The prevailing view, however, was to include a right to press publications without limiting it to digital publications only.
}

${ }^{12}$ European Parliament (Rapporteur: Catherine Stihler), Draft Opinion of the Committee on the Internal Market and Consumer Protection for the Committee on Legal Affairs on the proposal for a Directive of the European Parliament and of the Council on Copyright in the Digital Single Market, COM(2016)0593 - C8-0383/2016 2016/0280(COD), PE 599.682v01-00, IMCO_PA(2017)599682, amendment 61 (Feb. 20, 2017).

${ }^{13}$ European Parliament (Rapporteur: Catherine Stihler), Opinion of the Committee on the Internal Market and Consumer Protection for the Committee on Legal Affairs on the proposal for a Directive of the European Parliament and of the Council on Copyright in the Digital Single Market, COM(2016)0593 - C8-0383/2016 - 2016/0280(COD), PE 599.682v02-00, IMCO_AD(2017)599682 (June 14, 2017).

${ }^{14}$ European Parliament (Rapporteur: Marc Joulaud), Opinion of the Committee on Culture and Education for the Committee on Legal Affairs on the Proposal for a Directive of the European Parliament and of the Council on Copyright in the Digital Single Market, COM(2016)0593 - C8-0383/2016 - 2016/0280(COD), PE595.591v03-00, CULT_AD(2017)595591 (Sept. 4, 2017); European Parliament (Rapporteur: Marc Joulaud), Draft Opinion of the Committee on Culture and Education for the Committee on Legal Affairs on the Proposal for a Directive of the European Parliament and of the Council on Copyright in the Digital Single Market, COM(2016)0593 - C80383/2016 - 2016/0280(COD), PE595.591v01-00, CULT_PA(2017)595591 (Feb. 6, 2017).

15 See European Parliament (Rapporteur: Therese Comodini Cachia / Rapporteur for the opinion: Catherine Stihler), Draft Report of the Committee on Legal Affairs on the Proposal for a Directive of the European Parliament and of the Council on Copyright in the Digital Single Market, COM(2016)0593 - C8-0383/2016 2016/0280(COD), PE 601.094v01-00, JURI_PR(2017)601094 (Mar. 10, 2017). 
Member States, such as Estonia and the United Kingdom, voiced reservations on the proposed right, while only France, Italy and Spain offered their unambiguous support. ${ }^{16}$

The proposal has also received intense criticism from scholars across Europe, ${ }^{17}$ even before the proposed Directive was published, ${ }^{18}$ in that it is unnecessary, undesirable, fundamentally misconceived, and unlikely to achieve anything apart from adding to the complexity and cost of operating in the copyright environment.

Indeed, the proposed right to press publications, as incorporated in Article 11 of the proposed Directive, is not appropriate in addressing concerns of press publishers in light of digital technologies and, at the same time, is not adequately restricted to addressing such concerns. As I explain below, the proposed right covers too broad a subject matter, its scope and duration are excessive, it introduces an additional layer of protection without clear and sufficient evidence justifying the need for it, and it affects

${ }^{16}$ Matthew Karnitschnig \& Chris Spillane, Plan to make Google Pay for News Hits Rocks: The Adoption of a So-
called Publisher's Right would Reverberate around the World, POLITICO (Feb. 15, 2017, 7:36 PM CET; Updated
Feb. 17, 2017, 3:34 PM CET), http://www.politico.eu/article/plan-to-make-google-pay-for-news-hitsFeb. 17, 2017, 3:34 PM CET), http://www.politico.eu/article/plan-to-
rocks-copyright-reform-european-commission/ (last access Nov. 8, 2017).

${ }^{17}$ See indicatively Lionel Bently et al, Response to Article 11 of the Proposal for a Directive on Copyright in the Digital Single Market, entitled Protection of Press Publications concerning Digital Uses' on behalf of 37 Professors and Leading Scholars of Intellectual Property, Information Law and Digital Economy, 1 (Dec. 5, 2016), https://www.cipil.law.cam.ac.uk/sites/www.law.cam.ac.uk/files/images/www.cipil.law.cam.ac.uk/docume nts/ipomodernisingipprofresponsepresspublishers.pdf (last access Nov. 8, 2017); also see P. Bernt Hugenholtz, Say Nay to the Neighbouring Right, KLuwer Copyright Blog (Apr. 14, 2016), http://kluwercopyrightblog.com/2016/04/14/say-nay-to-the-neighbouring-right/ (last access Nov. 8, 2017); Copyright Reform: Open Letter from European Research Centres (Feb. 24, 2017), http://www.create.ac.uk/wp-

content/uploads/2017/02/OpenLetter_EU_Copyright_Reform_24_02_2017.pdf (last access Nov. 8, 2017); Raquel Xalabarder, Press Publisher Rights in the Proposed Directive on Copyright in the Digital Single Market, CREATE WORKING PAPER 2015/16, Dec. 2016, 17 et seq, https://zenodo.org/record/183788/files/CREATe-Working-Paper-2016-15.pdf (last access Nov. 8, 2017); Matthew Karnitschnig \& Chris Spillane, Plan to make Google pay for News Hits Rocks, id.; Christophe Geiger, Oleksandr Bulayenko \& Giancarlo F. Frosio, The Introduction of a Neighbouring Right for Press Publisher at EU Level: the Unneeded (and Unwanted) Reform, 39(4) EUROPEAN INTELLECTUAL PROPERTY REVIEW 202 (2017); Martin Senftleben, Maximilian Kerk, Miriam Buiten \& Klaus Heine, New Rights or New Business Models? An Inquiry into the Future of Publishing in the Digital Era, 48(5) INTERNATIONAL REVIEW OF INTELLECTUAL PROPERTY AND COMPETITION LAW 538 (2017).

${ }^{18}$ See e.g. Martin Kretschmer, Severine Dusollier, Christophe Geiger \& P. Bernt Hugenholtz, The European Commission's Public Consultation on the Role of Publishers in the Copyright Value Chain: A Response by the European Copyright Society, 38(10) EUROPEAN INTELLECTUAL ProperTy REVIEW 591 (2016); Martin Senftleben, Copyright Reform, GS Media and Innovation Climate in the EU - Euphonious Chord or Dissonant Cacophony?, 5 Tijdschrift VOOR Auteurs-, MediA- EN INFOrmatierecht 130-133 (2016); Ana Ramalho, Beyond the Cover Story - an Enquiry into the EU Competence to Introduce a Right for Publishers, 48(1) INTERNATIONAL ReVIeW OF InTELlectual Property AND Competition LaW 71 (2017); Reto M. Hilty, Kaya Köklü \& Valentina Moscon, Position Statement of the Max Planck Institute for Innovation and Competition on the Public Consultation on the Role of Publishers in the Copyright Value Chain' (June 15, 2016), http://www.ip.mpg.de/fileadmin/ipmpg/content/aktuelles/MPI_Position_statement_15_6_2016_def.pdf (last access Nov. 8, 2017). 
copyright law without addressing issues of licensing and enforcement which are the source of concerns on the future of press publishing. It is for these reasons that it is herein argued that a press publication right should not be included in EU law.

\section{ii. The rationale for a right to press publications}

The proposal for a related right to press publications followed a public consultation on the role of publishers in the copyright chain launched by the Commission in early 2016. Its purpose was-among other things— to collect views on the desirability of granting an EU neighbouring right to publishers and on whether the need for EU intervention should be different in the press sector compared to other sectors. Indeed, the Impact Assessment on the Modernisation of EU Copyright Rules states that:

[t]he shift from print to digital has enlarged the audience of press publications but made the exploitation and enforcement of the rights in publications increasingly difficult. In addition, publishers face difficulties as regards compensation for uses under exceptions. ${ }^{19}$

In order to address this issue, the proposal for a Directive on Copyright in the Digital Single Market included two relevant provisions: one provision for press publishers (Article 11) and another for publishers in general (Article 12). The former provision lays out a related right and the latter a share in the authors' compensation, so that when authors are compensated for an exception or limitation, the publishers may also be entitled to that revenue.

As Recital 31 indicates, it is the right to access to information that justifies the publishers' need for a related right under Article $11 .{ }^{20}$ Indeed, according to this Recital:

\footnotetext{
${ }^{19}$ European Commission, SWD(2016) 301 final, supra note 2, Vol. 1, 5.3.1, 155.

${ }^{20}$ For an analysis of the justification of the proposed right see: Mireille M.M. Van Eechoud, A Publisher's Intellectual Property Right: Implications for Freedom of Expression, Authors and Open Content Policies, OPEN FORUM EUROPE (Jan. 2017), http://www.openforumeurope.org/wp-content/uploads/2017/01/OFE-AcademicPaper-Implications-of-publishers-right_FINAL.pdf (last access Nov. 8, 2017); Alexander Peukert, An EU Related Right for Press Publishers Concerning Digital Uses, A Legal Analysis, GOETHE UNIVERSITY FrANKFURT AM MAIN, Research Paper of the Faculty of Law No. 22/2016 (Dec. 16, 2016), https://www.eco.de/wpcontent/blogs.dir/copyright_-legal-analysis.pdf (last access Nov. 8, 2017); Richard Danbury, Is an EU Publishers' Right a Good Idea? Final Report on the AHRC Project: Evaluating Potential Legal Responses to Threats to the Production of News in a Digital Era, CAmbridge: Centre FOR InTELleCtual Property AND INFORMATION LAW (June 2016),
} 
A free and pluralist press is essential to ensure quality journalism and citizens' access to information. It provides a fundamental contribution to public debate and the proper functioning of a democratic society. In the transition from print to digital, publishers of press publications are facing problems in licensing the online use of their publications and recouping their investments. In the absence of recognition of publishers of press publications as rightholders, licensing and enforcement in the digital environment is often complex and inefficient.

The fundamental right on access to information has been applied in other legislative instruments on copyright too, such as the Berne Convention, but with the view to justifying the exception for press summaries, ${ }^{21}$ instead of an exclusive right. The Commission's Impact Assessment offers further explanations for the need to establish an exclusive right for publishers: that it would address the need to strengthen their bargaining position vis-à-vis online platforms, facilitate licensing and help the development of new business models.

However, even though the Commission offers statistical evidence on the extent of the so-called 'newspaper crisis', ${ }^{22}$ the claims on the causal relationship between the introduction of a press publishers' intellectual property right and the increase in the revenues of the press leading to media diversity are neither supported not substantiated with data. For instance, the evidence presented by the Commission does not justify how the restriction of news communication will address the problem of declining advertising revenues of traditional newspapers. Neither the Impact Assessment ${ }^{23}$ nor the Commission Communication ${ }^{24}$ explain how the introduction of an additional layer of rights would facilitate rights clearance for online uses and reduce transaction costs for all stakeholders concerned.

https://www.cipil.law.cam.ac.uk/sites/www.law.cam.ac.uk/files/images/www.cipil.law.cam.ac.uk/docume nts/copyright_and_news/danbury_publishers_right_report.pdf (last access Nov. 8, 2017).

${ }^{21}$ See e.g. Art 10(1) of the Berne Convention for the Protection of Literary and Artistic Works of Sept. 9, 1886 as last amended on Sept. 28, 1979.

22 See European Commission, SWD(2016) 301 final, supra note 2, Vol. 1, 155.

${ }^{23}$ Id. Vol. 3, at 175-176, Annex 13.

${ }^{24}$ Communication from the Commission to the European Parliament, the Council, the European Economic and Social Committee and the Committee of the Regions: Promoting a Fair, Efficient and Competitive European Copyright-based Economy in the Digital Single Market, COM(2016)592 (Sept. 14, 2016). 
If the main concerns are about making licensing easier and enforcement more effective, the creation of an additional layer of rights is certainly not the most appropriate solution. It has been convincingly argued that an amendment of Article 5 of the Enforcement Directive, ${ }^{25}$ indicating that press publishers are entitled to bring proceedings to enforce the copyright in materials of which they are the identified publishers, would be a more effective way of addressing difficulties in enforcement. ${ }^{26} \mathrm{~A}$ proposal along these lines has made its way to the draft Report of the JURI Committee. ${ }^{27}$ The amendment states:

Member States shall provide publishers of press publications with a presumption of representation of authors of literary works contained in those publications and the legal capacity to sue in their own name when defending the rights of such authors for the digital use of their press publications. ${ }^{28}$

The controversial nature of the Commission's proposal is reflected in the tabled amendments, most of which suggest deleting Article 11 altogether, ${ }^{29}$ whereas others suggest allowing a press publisher right as an option for Member States. ${ }^{30}$

At the same time, although it is often said that news aggregation services are primarily responsible for the 'newspaper crisis', studies indicate that news aggregators are more likely to have a complementary ${ }^{31}$ rather than substitution effect on the number of homepage visits received by newspapers. ${ }^{32}$ There is indeed evidence that news aggregators increase web traffic to news publishers' websites. ${ }^{33}$ Independent studies also

\footnotetext{
${ }^{25}$ Directive 2004/48/EC of the European Parliament and of the Council of Apr. 29, 2004 on the Enforcement of Intellectual Property Rights, OJ L 157 (Apr. 30, 2004).

${ }^{26}$ Copyright Reform, supra note 17, 3; Bently et al, supra note 17, 2.

${ }^{27}$ European Parliament, Draft Report, PE 601.094v01-00,JURI_PR(2017)601094, supra note 15.

${ }^{28}$ Id. amendment 52. According to amendment 53, the proposal specifies by way of a new Article 11(1a) that the presumption does not apply in criminal proceedings.

${ }^{29}$ PE604.543 and PE604.544, tabled amendments 631, 732, 733, 734, 735, 736; 743, 744, 745, 765, 766, 767, 771, 772, 773, 774, 777, 778, 779, 780, and corresponding Amendments deleting recitals (Apr. 28, 2017).

${ }^{30}$ PE603.010, tabled amendments 299, 334, 348 (Apr. 28, 2017).

${ }^{31}$ See also in this regard Eleonora Rosati, Neighbouring Rights for Publishers: are National and (Possible) EU Initiatives Lawful?, 47(5) INTERNATIONAL REVIEW OF INTELLECTUAL PROPERTY AND COMPETITION LAW 571, 572 (2017).

${ }^{32}$ Chrysanthos Dellarocas, Juliana Sutanto, Mihai Calin \& Elia Palme, Attention Allocation in Information-Rich Environments: the Case of News Aggregators, 62(9) MANAGEMENT SCIENCE 2543 - 2562 (Dec. 10, 2015).

33 See Jason M.T. Roos, Carl F. Mela \& Ron Sacher, The Effect of Links and Excerpts on Internet News Consumption, S.S.R.N. (Sept. 24, 2015), https://papers.ssrn.com/sol3/papers.cfm?abstract_id=2678938
} 
indicate that the proposed right will have a negative impact on publishers, authors and journalists, and consumers and citizens alike. For instance, according to a study by the European Digital Media Association (EDiMA), ${ }^{34}$ the introduction of a publishers' right in Spain has caused publishers-particularly smaller ones-to lose as much as $14 \%$ of their web traffic, estimated to cost the Spanish news publishing industry $€ 10$ million a year. According to the same study, the proposed right will also increase the search costs for citizens as access to news from aggregators and applications will become more difficult. In Spain, for instance, the introduction of the publishers' right resulted in a loss of $€ 1.85$ billion a year for consumers, whereas in Germany, 57\% of the consumers find text 'snippets' helpful.

\section{iii. The (not so successful) national examples}

The European Commission's proposal for a right to press publications follows a number of ineffective national initiatives introduced with a view to recouping revenues that press publishers allegedly lose due to digitisation and the development of neighbouring distribution channels. ${ }^{35}$

Germany introduced a press publishers' right with effect from 1 August 2013. Sections $87 \mathrm{f}, 87 \mathrm{~g}$ and $87 \mathrm{~h}$ of the Urheberrechtsgesetz (German Copyright Act) offer

(last access Nov. 8, 2017); other sources of empirical data include Susan Athey, Mark Mobius \& Jeno Pal, The Impact of News Aggregators on Internet News Consumption: The Case of Localization Stanford Business School, STANFORD BusINESS, Working Paper No. 3353 (Jan. 11, 2017), https://www.gsb.stanford.edu/facultyresearch/working-papers/impact-news-aggregators-internet-news-consumption-case-localization (last access Nov. 8, 2017); Joan Calzada \& Ricard Gil, What Do News Aggregators Do? Evidence from Google News in Spain and Germany, S.S.R.N. (Sept. 11, 2016), https://papers.ssrn.com/sol3/papers.cfm?abstract_id=2837553; The impact of Web Traffic on Revenues of Traditional Newspaper Publishers: A study for France, Germany, Spain, and the UK, Deloitte (Mar. 2016), https://www2.deloitte.com/content/dam/Deloitte/uk/Documents/technology-media-

telecommunications/deloitte-uk-impact-of-web-traffic-on-newspaper-revenues-2016.pdf (last access Nov. 8, 2017).

A contrario, a German press publisher who objected to the use of regular snippets in Google's general search service, experienced a 40\% reduction of traffic on its websites. See Landgericht Berlin 92 O 5/14 (Feb. 19, 2016).

34 See Directive Copyright in the Digital Single Market: The Impact of Article 11 - Publisher Rights, EDIMA \& DigITAL EUROPE, http://edimaeu.org/pdfs/latest_news/EDiMA\%20DE\%20Policy\%20Brief\%20on\%20Publisher\%20Rights.pdf (last access Nov. 8, 2017).

35 Igor Barabash, Ancillary Copyright for Publishers: the End of Search Engines and News Aggregators in Germany?, 35(5) European InTEllectual Property REVIEW 243 (2013); See in general Rosati, supra note 31; for the proposed legislative solutions see Silvia Scalzini, Is there Free-Riding? A Comparative Analysis of the Problem of Protecting Publishing Materials in Europe, 10(6) J.I.P.L.P. 454, 461-463 (2015). 
press publishers the right to exploit their publications at commercial level for one year, thereby preventing third parties from making excerpts from newspaper articles available without obtaining a licence. ${ }^{36}$ Section $87 \mathrm{f}(2)$ of the Urheberrechtsgesetz defines press products as the technical, editorial determination of journalistic contributions that periodically appear under a title on any medium and include, in particular, articles and illustrations, which serve to convey information, opinion, or entertainment. It is only when individual words or very small text excerpts are copied that press publishers do not have a claim. ${ }^{37}$ This is an internal limit of the ancillary right, the scope of which has been clarified by the Arbitration Board of the German Patent and Trade Marks Office. On application of a collecting society, VG Media, for clarification on the press publisher tariff, the Board specified that the ancillary right covers only publications that are longer than seven words, excluding the search terms. ${ }^{38}$ The ancillary right lasts for one year only, ${ }^{39}$ it is transferrable, ${ }^{40}$ and it creates an entitlement to remuneration. ${ }^{41}$ This is a unique aspect of the right, in that authors too are provided with the right to participate in remuneration, according to section $87 \mathrm{~h}$ : German law does not only compensate press publishers' investment, but it also ensures that authors have a reasonable participation in remuneration for the use of their press products on the internet.

The German ancillary right was to a large extent rendered meaningless as—on the day that it entered into force-Google decided to make its Google News service 'opt-in' instead of 'opt-out'. ${ }^{22}$ This practically means that Google News would only feature results from those press publishers that have expressly opted in, and hence consented to, Google's indexing and showing to the public of their data in its news aggregator. Therefore, clearing a licence or paying remuneration according to the new German law

\footnotetext{
${ }^{36}$ Art. 87f(1), Urheberrechtsgesetz (German Copyright Act).

${ }^{37}$ Ibid.

38 Deutsches Patent- und Markenamt, (Sept. 24, 2015), https://www.dpma.de/service/dasdpmainformiert/hinweise/tarifpresseverleger/index.html (last access Nov. 8, 2017); also see Jakob Kucharczyk, A Legal' Snippet in Germany could Mean... Seven Words, Maximum, DISCO (Oct. 27, 2015), http://www.project-disco.org/intellectual-property/102715-a-legal-snippet-ingermany-could-mean-seven-words-maximum/\#.WY2g0xiZOCQ (last access Nov. 8, 2017).

${ }^{39}$ Art. 87g(2), Urheberrechtsgesetz (supra note 36).

${ }^{40}$ Ibid at Art. $87 \mathrm{~g}(1)$.

${ }^{41}$ Ibid at Art. $87 \mathrm{~h}$.

${ }^{42}$ Google News Bleibt Offene Plattform für Alle Deutschen Verlage, Der OFFIZIELLE GoOGLE ProduKT-BLOG June 21, 2013), https://germany.googleblog.com/2013/06/google-news-bleibt-offene-plattform-fuerverlage.html (last access Nov. 8, 2017).
} 
would not be necessary. Various German press publishers have since authorised Google to index their publications free of charge and to feature them in Google's News and Search services. ${ }^{43}$ Smaller news aggregation services operating in Germany delisted press publishers or stopped using snippets. ${ }^{44}$

Following Google's refusal to negotiate with VG Media and pay a reasonable compensation for the display of snippets, VG Media filed a complaint before the Copyright Arbitration Board of the German Patent and Trade Mark Office. The Board initially decided that Google ought to pay as the ancillary right applied. ${ }^{45}$ Google, however, categorically refused to recognise the applicability of the right and to pay the rightholders accordingly, making enforcement by the Berlin Regional Court necessary. By virtue of Directive 98/34/EC (as amended by Directive 98/48/EC), Member States ought to notify the Commission of 'technical regulations' they intend to adopt ${ }^{46}$ so as to allow the Commission to assess the impact of such a right on the internal market. ${ }^{47}$ Because of impeding elections in Germany, however, the German Government did not notify the Commission of their intention to introduce the ancillary right. In May 2017, the Berlin Court decided to stay proceedings ${ }^{48}$ and make a reference to the Court of Justice of the European Union (CJEU) for guidance on the lawfulness of the German ancillary right. ${ }^{49}$

\footnotetext{
43 See Andreas Becker, German Publishers vs. Google, DeUTSCHE WeLle (Oct. 30, 2014), http://dw.com/p/1DeXc (last access Nov. 8, 2017).

${ }^{44}$ See Kretschmer et al, supra note 18, 594.

${ }^{45}$ Deutsches Patent- und Markenamt, supra note 38.

${ }^{46}$ See in this regard Bo Vesterdorf, The Effect of Failure to Notify the Spanish and German Ancillary Copyright Laws, 37(5) EUROPEAN INTELLECTUAL PROPERTY REVIEW 263 (2015).

47 Antitrust questions regarding the abuse of market power by Google and the legality of its forced securing of consent are being considered in separate proceedings before the Berlin Court of Appeal and the European Commission. These issues play a subordinate role in the course of the copyright-related lawsuit.

${ }^{48}$ Landgericht Berlin, 16 O 546/15 (May 8, 2017).

${ }^{49}$ VG Media Gesellschaft zur Verwertung der Urbeber- und Leistungsschutzrechte von Medienunternehmen mbH v Google Inc, C-299/17, OJ C 309, 21-22 (Sept. 18, 2017). The questions are the following:
}

1. Does a national rule which prohibits only commercial operators of search engines and commercial service providers which edit content, but not other users, including commercial users, from making press products or parts thereof (excluding individual words and very short text excerpts) available to the public constitute, under Article 1(2) and (5) of Directive 98/34/EC (as amended by Directive 98/48/EC), a rule which is not specifically aimed at the services defined in that point,

and, if that is not the case, 
In 2014, the Spanish Parliament adopted a law, which-inter alia-reformed the quotation exception available under Article 32 of the Ley de Propiedad Intelectual (Intellectual Property Law). ${ }^{50}$ Under the new law, it is permissible to quote 'nonsignificant fragments of content available to the public' in cases where the content is available from periodicals or regularly updated websites, and where the content at issue has the purpose of providing information, creating public opinion, or entertainment. Even though it is not necessary to clear a license for such a use, the latter is subject to the payment of compensation to editors and other rightholders. Unlike the German ancillary right, the Spanish law introduces a copyright limitation in the form of an entitlement to equitable remuneration that cannot be waived.

Just before the Spanish law came into force, Google announced that it would discontinue its News service in Spain. ${ }^{51}$ Interestingly, recent empirical evidence demonstrates the positive impact of news aggregators on online news sites in Spain. In particular, in the first three months of 2015, the closing of news aggregation services, including Google News, has resulted in a decline of internet traffic to Spanish newspapers of over $6 \%$, with the decline having a stronger impact on small publications. $^{52}$

In its Impact Assessment, ${ }^{53}$ the Commission accepts that the initiatives in Germany and Spain have proved to be ineffective; seemingly attributing their failure to their domestic scope. The Impact Assessment suggests that the proposed right to press publications is, on the other hand, likely to be more effective and lead to greater legal

2. does a national rule which prohibits only commercial operators of search engines and commercial service providers which edit content, but not other users, including commercial users, from making press products or parts thereof (excluding individual words and very short text excerpts) available to the public constitute a technical regulation within the meaning of Article 1(11) of Directive 98/34/EC (as amended by Directive 98/48/EC), namely a compulsory rule on the provision of a service?

${ }^{50}$ For a critique of this provision see Xalabarder, supra note 17, 17 et seq; Raquel Xalabarder, The Remunerated Statutory Limitation for News Aggregation and Search Engines Proposed by the Spanish Government - Its Compliance with International and EU Law, INFOJUSTICE (Oct. 3, 2014), http://infojustice.org/archives/33346 (last access Nov. 8, 2017).

51 An Update on Google News in Spain, Google Europe Blog (Dec. 11, 2014), https://europe.googleblog.com/2014/12/an-update-on-google-news-in-spain.html (last access Nov. 8, 2017).

${ }^{52}$ See Pedro Posada de la Concha, Alberto Gutiérrez García \& Hugo Hernández Cobos, Impacto del Nuevo Artículo 32.2 de la Ley de Propiedad Intelectual, Informe para la Asociación Española de Editoriales de Publicaciones Periódicas, NERA (July 9, 2015), http://www.aeepp.com/pdf/InformeNera.pdf (last access Nov. 8, 2017).

${ }^{53}$ European Commission SWD(2016) 301 final, supra note 2, Vol. 1 at 159-160. 
certainty because of its pan-European effect. ${ }^{54}$ However, a group of press publishers have opposed the introduction of an ancillary right at EU level claiming that, as in the German and Spanish examples, such legislation 'is a step away from a forward-looking, modern and diverse European press. It will only make it harder for [them] to grow and develop innovative models. ${ }^{55}$

Moreover, unlike the German ancillary right that lasts for one year only and the Spanish provision that does not lay down a fully-fledged exclusive right, the Commission's proposal is even more radical and far-reaching than the national approaches in that it stipulates an exclusive right of 20 years' duration.

\section{iv. The excessive scope of the proposed right}

Article 11 outlines a related right of a 20 -year term in the form of a fully-fledged exclusive right to reproduce and make available to the public 'for digital use' any publisher's 'press publications', i.e. a right that is derived from, or subordinate to, copyright. The proposed right is meant to be compulsory for Member States to implement and it consists of more than mere compensation to the publishers. ${ }^{56}$

\footnotetext{
${ }^{54}$ Ibid at 166-167; contra: Maria Lillà Montagnani, The EU Consultation on Ancillary Rights for Publishers and the Panorama Exception: Modernising Copyright Through a 'One Step Forward and Two Steps Back' Approach, KLUwER COPYRIGHT BLOG (Sept. 20, 2016), http://kluwercopyrightblog.com/2016/09/20/the-eu-consultationon-ancillary-rights-for-publishers-and-the-panorama-exception-modernising-copyright-through-a-one-stepforward-and-two-steps-back-approach/ (last access Nov. 8, 2017).

55 Arsenio Escolar et al, Ancillary Copyright: Group of Press Publishers Write Letter to the European Commission, International Federation OF Reproduction Rights Organisation (Dec. 4, 2015), http://ifrro.org/content/ancillary-copyright-group-press-publishers-write-letter-europeancommission (last access Nov. 8, 2017).

${ }^{56}$ Other publishers, according to Article 12, will have a claim to share any compensation that the author receives for any exceptions and limitations that are available under national laws. Such exceptions and limitations cover reprography, private copying, and possibly the rental remuneration right. Article 12 of the Proposal reads:
}

Member States may provide that where an author has transferred or licensed a right to a publisher, such a transfer or a licence constitutes a sufficient legal basis for the publisher to claim a share of the compensation for the uses of the work made under an exception or limitation to the transferred or licensed right.

Unlike Article 11, Article 12 is not compulsory for Member States to implement ('Member States may provide...').

See, however, the relevant revision included in the Opinion of the European Parliament, where it is suggested that the provision of Article 12 is made mandatory for Member States to implement. See European Parliament, Opinion of the Committee on Culture and Education, PE595.591v03-00, CULT_AD(2017)595591, supra note 14, amendment 70. 
Even though the proposed right purports to increase the returns of the investments made by press publishers, and to simplify enforcement and licensing, the relevant provision raises both doctrinal and normative concerns. From a doctrinal point of view, the definition of press publication is ill-suited and creates uncertainty due to its extremely broad scope. Under the definition included in Article 2(4), facts or information are also covered. This is against established copyright principles, according to which protection does not extend to mere data. ${ }^{57}$ From a normative perspective too, the very creation of an exclusive right to press publications could lead to an unacceptable monopolisation of information through the expansion of copyright protection. As explained below, the proposed right could cover snippets and headlines embedding links that may not be covered by copyright protection.

The related right has hence not been endorsed as such by the various committees of the European Parliament. It was only the ITRE Committee that took a protectionist approach in its Opinion, expressing support for the view that print editions are worth as much protection as digital editions and therefore proposing the expansion of the right to all press publications. ${ }^{58}$ Yet an interesting aspect of the ITRE proposal is that it recognises that there should be limits to the right by expressly excluding its application to acts of hyperlinking "as they do not constitute communication to the public". ${ }^{59}$ The IMCO Committee, on the other hand, took a more radical approach and suggested the deletion of Article $11 .^{60}$ This was recommended due to the lack of sufficient justification in support of the right, with the Committee indicating that a revision of the Enforcement Directive would be more appropriate. It is worth noting that there was intense debate in both Committees over these and other amendments, including on whether the right should be deleted. ${ }^{61}$ These discussions may have strengthened the position of press

\footnotetext{
${ }^{57}$ See e.g. Article 9(2) of the Agreement on Trade-Related Aspects of Intellectual Property Rights 1994 (TRIPS Agreement).

58 European Parliament, Opinion of the Committee on Industry, Research and Energy, PE592.363v03-00, ITRE_AD(2017)592363, supra note 11, notably amendments 43 and 44.

${ }^{59} \mathrm{Id}$. amendment 45.

${ }^{60}$ European Parliament, Draft Opinion of the Committee on the Internal Market and Consumer Protection, PE 599.682v01-00, IMCO_PA(2017)599682, supra note 12, amendment 61.

${ }^{61}$ See European Parliament, Amendments 12-259 of the Committee on Industry, Research and Energy for the Committee on Legal Affairs Committee on Industry, Research and Energy on the Proposal for a Directive of the European Parliament and of the Council on Copyright in the Digital Single Market $(\operatorname{COM}(2016) 0593$ - C8-0383/2016 - 2016/0280(COD)), PE 592.364v01-00, ITRE_AM(2017)592364 (Apr. 5, 2017); See European Parliament, Amendments 63-303 of the Committee on the Internal Market and Consumer Protection for the Committee on Legal Affairs on the proposal for a Directive of the
} 
publishers in recognising an argument for enlarging the scope of protected uses to cover both digital and print uses. ${ }^{62}$

The CULT Committee set forth two main revisions that have to do with the scope of the proposed right - that should cover only press publications of a professional nature - and its duration. ${ }^{63}$ In particular, the Parliamentary Committee clarified that the relevant provision should include only business-to-business relationships and not cover private and non-commercial uses. ${ }^{64}$ What is more, it also suggested reducing the duration of the right to eight years, ${ }^{65}$ even though the initial proposal in its draft Opinion was for three years. ${ }^{66}$ The reason is that the average lifespan of press publications is considerably shorter than other types of copyright protected works, and a shorter duration would reflect the need to strike a balance with citizens' right to access information. An analogy can here be drawn to unregistered Community Designs. Unlike registered Community designs, which can be protected for a maximum of 25 years, unregistered Community designs are protected for a period of three years from the date on which the design was first made available to the public within the territory of the EU. As acknowledged in the preamble of Regulation 6/2002:

[s]ome ... sectors produce large numbers of designs for products frequently having a short market life where protection without the burden of registration formalities is an advantage and the duration of protection is of lesser significance. $^{67}$

European Parliament and of the Council on Copyright in the Digital Single Market, COM(2016)0593 - C80383/2016 - 2016/0280(COD), PE 602.819v01-00, IMCO_AM(2017)602819 (Apr. 5, 2017); European Parliament, Amendments 304-576 of the Committee on the Internal Market and Consumer Protection for the Committee on Legal Affairs on the proposal for a Directive of the European Parliament and of the Council on Copyright in the Digital Single Market, COM(2016)0593 - C8-0383/2016 - 2016/0280(COD), PE 602.820v01-00, IMCO_AM(2017)602820 (Apr. 5, 2017).

${ }^{62}$ European Parliament, Opinion of the Committee on the Internal Market and Consumer Protection, PE 599.682v0200, IMCO_AD(2017)599682, supra note 13, amendment 38.

63 European Parliament, Opinion of the Committee on Culture and Education, PE595.591v03-00, CULT_AD(2017)595591, supra note 14.

${ }^{64} \mathrm{Id}$. amendments 26 and 73.

${ }^{65} \mathrm{Id}$. amendment 78.

66 European Parliament, Draft Opinion of the Committee on Culture and Education, PE595.591v01-00, CULT_PA(2017)595591, supra note 14, amendment 69.

${ }^{67}$ Council Regulation (EC) No 6/2002 of Dec. 12, 2001 on Community designs, Recital 16. Also see Recital 25. 
These include fast-moving industries, such as the fashion industry. The same rationale could apply to press publications and news items.

An interesting approach was the one proposed by the Committee of Legal Affairs (JURI) in its draft report. Stressing the need for proportionality, the draft report envisages not a new right, but instead a presumption of ownership. ${ }^{68}$ This alternative option is less intrusive and more proportionate in dealing with the problems that press publishers face in the transition from print to digital. It aspires to simplify licensing mechanisms through the presumption that a press publisher has the relevant rights in the copyright protected content without having to demonstrate contractual transfers for each and every newspaper article.

\section{a. The definition of press publication}

The broad scope of the Commission's proposal is stressed by the very definition of protectable subject matter. According to Article 2(4) of the proposal, protectable subject matter includes 'a fixation of a collection of literary works of a journalistic nature.' This phrase seems to have a rather broad meaning, as demonstrated by the decision of the CJEU in Case C-73/07 Satamedia. ${ }^{69}$ In this case, the Court of Justice found that:

activities ... may be classified as 'journalistic activities' if their object is the disclosure to the public of information, opinions or ideas, irrespective of the medium which is used to transmit them. They are not limited to media undertakings and may be carried out for profit-making purposes..$^{70}$

The reference to 'journalistic nature' appears to be an inclusive phrase that covers literary works, except those that are meant for literary enjoyment only, such as literature or poetry. ${ }^{71}$ Some commentators indicate that, according to this phrase, it should be the works as such that have a journalistic nature, and not-for instance-the publisher or the medium of publication. This means that the publication of collections of certain

\footnotetext{
${ }^{68}$ European Parliament Draft Report, PE 601.094v01-00, JURI_PR(2017)601094, supra note 15, amendment 52.

69 Tietosuojavaltuntettu v. Satakunnan Markkinapörssi Oy, Satamedia Oy, Case C-73/07, [2008] ECLI:EU:C:2008:727 (Satamedia).

${ }^{70}$ Id. [64].

${ }^{71}$ See Bently et al, supra note 17, 9-10.
} 
kinds of subject matter, such as fixture lists, should be excluded from the concept of press publication. ${ }^{72}$

The definition of press publications also includes a second category of protected subject matter, covering 'other works or subject matter and constitut[ing] an individual item within a periodical or regularly-updated publication under a single title'. This appears to expand the subject matter beyond 'literary works of a journalistic nature', for instance, to works such as photographs or drawings. Recital 33 states that 'periodical publications which are published for scientific or academic purposes, such as scientific journals, should not be covered by the protection granted to press publications, ${ }^{, 73}$ yet this exclusion does not seem to align with the broad definition offered in the Article that affords protection to press publications 'having the purpose of providing information related to news or other topics. ${ }^{74}$ Such other topics could include scientific news or relevant information. This is broader than what the Commission seems to envisage.

The CULT Committee offered a revised definition of press publication under Article 2(4):

'press publication' means a professional fixation under a single title of a collection of literary works of a journalistic nature produced by one or several authors, which may also comprise other works or subject-matter and constitutes an individual item where:

(a) it occurs within a periodical or regularly-updated publication under a single title, such as a newspaper or a general or special interest magazine;

(b) its purpose is to provide information related to news or other topics; and

(c) it is published in any media under the editorial responsibility and control of a service provider. ${ }^{75}$

The most interesting addition of the CULT Committee's proposed revision-which does not feature in the JURI report-is the introduction of the element of a professional

\footnotetext{
${ }^{72} I d$. at 9.

${ }^{73}$ European Commission SWD(2016) 301 final, supra note 2, Vol. 1 at 158.

${ }^{74}$ Emphasis added. See in this regard Bently et al, supra note 17, 12.

75 European Parliament, Opinion of the Committee on Culture and Education, PE595.591v03-00, CULT_AD(2017)595591, supra note 14, amendment 43; the Committee retained the very similar definition it had suggested in its draft Opinion (PE595.591v01-00, CULT_PA(2017)595591, supra note 14, amendment 40 .
} 
nature of a protected press publication. Indeed, the CULT Committee's main concern is that the right to press publications should be limited to business-to-business relationships and that private and non-commercial uses should not be covered by the new right. Another aspect that is worth mentioning is that the three satellite conditions incorporated in the definition of press publication are listed in a cumulative way, thereby further limiting its scope.

\section{b. Snippets, linking, and other digital uses}

According to Article 11 of the proposed Directive, press publishers are given the exclusive right of reproduction and the right of making available to the public. Both rights are granted for the digital use of press publications. As Recital 34 to the proposed Directive indicates, the rights granted to the publishers of press publications should have the same scope as the rights of reproduction and making available to the public provided for in the Information Society Directive (2001/29/EC), insofar as digital uses are concerned.

It is not clear, however, what kinds of uses the proposed right will cover. Recital 33 indicates that protection does not extend to acts of hyperlinking that do not constitute communication to the public. In Svensson ${ }^{76}$ and other cases of the CJEU, ${ }^{77}$ hyperlinking was found to not amount to an act of exploitation when the communication of the work was not addressed to a new public. ${ }^{78}$ This was notably the case of links to materials that were freely available to the public at large and not subject to access restrictions. This position was revisited in 2016, in GS Media, ${ }^{79}$ where the CJEU held that, where the material has not been made available with the consent of the rightholders, links to such content would amount to infringement if the linker had knowledge of the status of the material. In paragraph 51 of the judgment, the CJEU held that:

... when the posting of hyperlinks is carried out for profit, it can be expected that

\footnotetext{
${ }^{76}$ Nils Svensson and Others v. Retriever Sverige AB, Case C-466/12, [2014] ECLI:EU:C:2014:76 (Svensson).

77 BestWater International GmbH v. Michael Mebes, Stefan Potsch, Case C-348/13, [2014] ECLI:EU:C:2014:2315 (order of the Court) (BestWater).

78 Svensson; BestWater, also see Stavroula Karapapa, The requirement for a 'new public' in EU copyright law, 1 EUROPEAN LAW REVIEW 63 (2017).

${ }^{79}$ GS Media BV v. Sanoma Media Netherlands BV, Playboy Enterprises International Inc., Britt Geertruida Dekeker, Case C-160/15, [2016] ECLI:EU:C:2016:644 (GS Media).
} 
the person who posted such a link carries out the necessary checks to ensure that the work concerned is not illegally published on the website to which those hyperlinks lead, so that it must be presumed that that posting has occurred with the full knowledge of the protected nature of that work and the possible lack of consent to publication on the internet by the copyright holder.

Knowledge is presumed for the linkers as commercial operators are expected to investigate the status of the materials to which they link. This could be read to mean that, when for-profit posting of materials takes place, the linkers should be diligent in ensuring lawful and consensual publication, possibly by consulting press publishers, otherwise their activities will amount to infringement. Those who are not placing links for profit are not liable however, absent knowledge on the status of the material. ${ }^{80}$

If linking that does not constitute communication to the public is not to be included within the scope of the right to press publication, there are two other instances that could be covered by the right. These are snippets and digital uses other than mere linking, such as showing headlines enabling links. According to EU data, ${ }^{81}$ most online users read only the headlines and a featured snippet instead of clicking on the link that would take them to publishers' websites. Those readers would not increase the press publishers' web traffic. Under the new right, snippets and active-link headlines would only be exempt from infringement when covered by the exemption available for temporary copies under Article 5(1) of the Information Society Directive (2001/29/EC). The exemption covers acts of temporary reproduction that are an integral and essential part of a technological process aimed at availing of a lawful use of the work, providing that the act has no independent economic significance.

In Infopaq I, Article 5(1) was found to apply to some, but not all, phases of the process of extracting snippets from newspapers articles, namely those phases where the deletion of the temporary copy is automatic and not dependent upon discretionary human intervention. In Infopaq II, ${ }^{83}$ however, the CJEU decided that acts of temporary

\footnotetext{
${ }^{80}$ Id. [47].

${ }^{81}$ See the European Commission, Flash Eurobarometer 437 (fieldwork Mar. 2016, published Sept. 2016), http://ec.europa.eu/COMMFrontOffice/publicopinion/index.cfm/Survey/getSurveyDetail/instruments/ FLASH/surveyKy/2123 (last access Nov. 8, 2017).

${ }^{82}$ Infopaq International A/S v. Danske Dagblades Forening, C-5/08, [2010] F.S.R. 495 (Infopaq I).

${ }^{83}$ Infopaq International A/S v. Danske Dagblades Forening, C-302/10, [2012] ECLI:EU:C:2012:16 (Infopaq II)
} 
copying may be exempt even if they involve human intervention, provided that they are an integral and essential part of a technological process. To the extent that the temporary copying exemption applies, search engines and news aggregators would not be affected by the proposed related right on press publications. It would only be a matter of how the meaning of 'no independent economic significance' will be construed in this context. Snippets are likely to benefit from Article 5(1) when they are merely part of a technological process of searching. ${ }^{84}$ When, however, search engines and news aggregators make editorial choices by reference to the news items, the exception will certainly not apply.

Article 11(3) and Recital 34 also state that both rights should be subject to the same provisions on exceptions and limitations as those applicable to the rights provided for in the Information Society Directive (2001/29/EC), including the exception on quotation for purposes such as criticism or review laid down in Article 5(3)(d) of that Directive. ${ }^{85}$ Digital uses, such as scanning and indexing, that are at the core of the activity of many news monitoring services or libraries, and that are not fully covered by any exception or limitation, will be included within the scope of the proposed right to press publications.

\section{c. Towards the monopolisation of information?}

As we have seen above, press publications mainly involve news items. News, however, has remained for a long time outside the scope of copyright laws. For instance, Article 2(8) of the Berne Convention clearly states that ' $\mathrm{t}]$ he protection of this Convention shall not apply to news of the day or to miscellaneous facts having the character of mere items of press information.' If snippets, headlines incorporating links, and other digital uses, such as non-permitted text mining, are to be covered by the proposed right to press

\footnotetext{
${ }^{84}$ Snippets could be covered by Article 10(1) of the Berne Convention that sets an exception for quotations made for press summaries. According to this provision:

It shall be permissible to make quotations from a work which has already been lawfully made available to the public, provided that their making is compatible with fair practice, and their extent does not exceed that justified by the purpose, including quotations from newspaper articles and periodicals in the form of press summaries.

${ }^{85}$ See however the decision of the Court of Justice in Hewlett-Packard Belgium SPRL $v$. Reprobel SCRL, Case C-572/13, [2015] ECLI:EU:C:2015:750 (Reprobel) at [47], where the Court found that publishers are not among the reproduction rightholders listed in Article 2 of the Information Society Directive (2001/29/EC) but they are also not entitled to any fair compensation for the harm that copyright exceptions may cause.
} 
publications, it is very likely that the protection thereby afforded would be more akin to protecting information than offering protection to original subject matter as such.

This raises the question as to how far copyright law should go. Should each and every digital use of the work be restricted by copyright? The proposal for a Directive seems to imply that this is to be answered in the affirmative. It is not a surprise that the European Parliament's suggested revisions indicate that the proposed right to press publications ought to be more clearly limited in terms of scope and duration or, alternatively, removed altogether from the proposed Directive. Copyright has never been about the protection of information and the proposed Directive tends to confuse copyright protected subject matter and mere information by seemingly extending protection to snippets, headlines, and some forms of text mining. ${ }^{86}$

\section{v. Why the proposed right to press publications should be deleted or replaced with a meaningful alternative}

Since the right to press publications was announced, it has been subject to intense criticism. ${ }^{87}$ In its draft Opinion, the IMCO Committee suggested the deletion of Article 11 on the basis that it arguably lacked sufficient justification and was not appropriate in achieving its objectives. ${ }^{88}$ The proposed right has also been the focus of legal scholarship. For instance, a group of thirty-seven intellectual property professors has stated that:

the proposed right is unnecessary, undesirable, would introduce an unacceptable level of uncertainty and be unlikely to achieve anything apart from adding to the complexity and cost of operating in the copyright environment. ${ }^{89}$

A main criticism on the proposed right on press publications has to do with the lack of clear evidence justifying the creation of such a right. There is no evidence to support the claim that search engines and news aggregators are behind the loss of press

\footnotetext{
${ }^{86}$ What is more, in light of the generally established principle that copyright arises as a matter of originality rather than length, the decision of the German Patent and Trade Marks Office that the German ancillary right covers only publications that are longer than seven words seems to be equally confusing. Deutsches Patent- und Markenamt, supra note 38.

${ }^{87}$ See indicatively Bently et al, supra note 17, 1; Xalabarder, supra note 17.

${ }^{88}$ European Parliament, Draft Opinion of the Committee on the Internal Market and Consumer Protection, PE 599.682v01-00, IMCO_PA(2017)599682, supra note 12, amendment 61.

${ }^{89}$ See Bently et al, supra note 17, 1.
} 
publishers' revenue. As explained earlier, the data that has been included in the Impact Assessment do not convincingly demonstrate how the proposed right to press publications would have an impact on the declining revenue of press publishers. ${ }^{90}$ Neither the Impact Assessment ${ }^{91}$ nor the Commission Communication ${ }^{92}$ explain how the introduction of an additional layer of rights would facilitate rights clearance for online uses and reduce transaction costs for all stakeholders concerned.

Part of the argument is that press publishers have been derivative owners of the authors' exclusive rights for many years. If the problems facing press publishers are related to licensing and enforcement as indicated in the Impact Assessment, a more direct solution to the problem would be more efficient than the introduction of a new right. The JURI draft report and certain scholars rightly suggest that the aim of simplifying enforcement could have been achieved by amending Article 5 of the Enforcement Directive with a view to creating a presumption that press publishers are entitled to enforce copyright in any item that they publish. A defendant would have to rebut such a presumption by demonstrating that the material was in the public domain or licensed by its author. ${ }^{93}$ What is more, publishers can rely on the database right ${ }^{94}$ to prevent extraction and reutilisation of their protected content, to the extent that their online news site falls within the definition of database.

Another aspect of the right that is worth further attention is that it is not likely to meet its primary objective, namely to empower press publishers, especially vis-à-vis its overlap with authorial entitlements. Article 11(2) of the proposal states that author's rights incorporated in the press publication 'may not be invoked against those authors and other rightholders and, in particular, may not deprive them of their right to exploit their works and other subject matter independently from the press publication in which

\footnotetext{
$9^{90}$ Van Eechoud, supra note 20, at 11.

${ }^{91} \operatorname{SWD}(2016) 301$ final, supra note 2, Vol. 3 at 175-176, Annex 13.

${ }_{92} \operatorname{COM}(2016) 592$, supra note 24.

93 See European Parliament, Draft Report, PE 601.094v01-00, JURI_PR(2017)601094, supra note 15, amendment 52; Lionel Bently et al, Strengthening the Position of Press Publishers and Authors and Performers in the Copyright Directive, Study for the JURI Committee, Policy Department for Citizens' Rights and Constitutional Affairs Directorate General for Internal Policies of the Union, PE 596.810 (Sept. 2017); Bently et al, supra note 17 , at 22 .

${ }^{94}$ See Directive 96/9/EC of the European Parliament and of the Council of 11 March 1996 on the legal protection of databases, OJ L 77 (Mar. 27, 1996).
} 
they are incorporated.' Similar is indicated in Recital $35 .{ }^{95}$ However, press publishers already acquire the authors' copyright through employment contracts or contracts with freelance journalists and, in this light, the proposed right establishes two layers of rights for the same creation. ${ }^{96}$ In this regard, the proposed right will simply duplicate existing entitlements, without making a meaningful addition to the publishers' portfolio of intellectual property protection.

\section{vi. Conclusion}

The proposed related right of press publishers aims to offer an additional layer of protection to press publications with a view to ensuring sustainability of the press and simplifying the process of concluding licenses and enforcing rights. Although digitisation has been marked by a decline of revenues in the press publishing sector, and by the drop of newspaper advertising sales in Europe, the proposed right is neither an adequate nor a proportionate measure in dealing with the so-called 'newspaper crisis'. There is indeed no hard evidence that the right can achieve its stated objectives and its design is questionable both in terms of scope and duration, with the likely effect that the protection thereby afforded would be more akin to the protection of information instead of original subject matter.

It is true that press publishers depend on the enforcement of their derivative rights in order to protect the investment on their publications and to assert the rights they hold by law or by means of assignment, licence or any other contractual arrangement. In this light, measures to strengthen their enforcement position are necessary. Such measures, however, should not disrupt other industries and they should be proportionate towards the achievement of the stated objectives, including the need for an open internet and a free, pluralist press. At a time that some news aggregators have entered into voluntary licensing agreements with major publishers, an adequate policy solution would require the simplification of licensing mechanisms at pan-European level.

\footnotetext{
${ }^{25}$ This Recital indicates that 'publishers of press publications should not be able to invoke the protection granted to them against authors and other rightholders. This is without prejudice to contractual arrangements concluded between the publishers of press publications, on the one side, and authors and other rightholders, on the other side.'

${ }^{96}$ Copyright Reform, supra note 17.
} 
Even though there may not be sufficient evidence to support the introduction of a press publisher right, there is enough to support a solution that would empower press publishers by protecting their legal entitlement, whilst safeguarding the plurality of news and opinions on the internet. Licensing could be simplified through a presumption of representation of authors, according to which press publishers are entitled to enforce copyright in items they publish. European policies should adapt the regulatory framework to the emergent transition from print to digital affecting the news sector. It is perhaps in this way that the parameters for quality journalism and citizens' access to information may not only be set but also reinforced as essential values in the proper functioning of a democratic society. 